\title{
Tsvetaeva in English: A Review Article ${ }^{1}$
}

I n June 1923 Marina Tsvetaeva, then living in the village of Mokropsy outside of Prague, wrote to the young literary critic Aleksandr Bakhrakh, contributor to Russian émigré publications in Berlin. The correspondence between the poet and the critic, who at that time had not yet met in person, soon took on a tone of strong emotional involvement. By August Tsvetaeva realized that she had misinterpreted the tenor of Bakhrakh's letters and that the excessive intimacy of their correspondence was making him uncomfortable. Her later letters to him are accordingly far less personal or intense in tone. The temporary emotional crisis into which Tsvetaeva's correspondence with Bakhrakh plunged her is also reflected in eight remarkable poems which she appended in her letters to him. ${ }^{2}$ Seven of these poems were eventually included in Tsvetaeva's finest and most mature collection, Posle Rossii (After Russia). The seventh poem of the sequence addressed to Bakhrakh, untitled when sent to him, was given the title "Pis'mo" (Letter) in the collection. ${ }^{3}$ Written on 11 August 1923, the poem depicts the poet's agony of waiting for Bakhrakh's reply to the several letters she had sent him, asking him to define their relationship and the future of their correspondence.

This poem has a rather curious history of publication. After what apparently was its first appearance in print in Posle Rossii, it was included (as a new and unpublished poem) in 1946 in the collection Russkii sbornik, which also contained Bakhrakh's obituary of Tsvetaeva. ${ }^{4}$ In 1961, Bakh-

1 Originally published as "Cvetaeva in English: A Review Article" in Slavic and East European Journal 10, no. 2 (1966): 191-96.

2 Marina Tsvetaeva's letters to Aleksandr Bakhrakh appeared in Mosty, no. 5 (1960): 299-318, and no. 6 (1961): 319-41. The poem "Pis'mo," in the form originally mailed to Bakhrakh, is reproduced in no. 6, 345-46.

3 M. Tsvetaeva, Posle Rossii (Paris, 1928), 108-9.

4 Russkii sbornik (Paris, 1946), 136. In this edition, line 5 of the poem is erroneously placed at the beginning. There are minor textual differences between the version sent to Bakhrakh (the one in Mosty and in Russkii sbornik) and Tsvetaeva's final version, which appears in Posle Rossii and in Tarusskie stranitsy. 
rakh included "Pis'mo" in his publication of Tsvetaeva's letters and poems addressed to him. In the same year the poem was finally published in the Soviet Union, along with a number of other poems from Posle Rossii, in the celebrated, much-criticized by the orthodox, collection Tarusskie stranitsy. ${ }^{5}$ Although the magnificent poetry of Posle Rossii has been available in Western libraries for decades, it is typical and significant that it was only after the furor occasioned by Tarusskie stranitsy and its hostile reception by some Soviet critics that some of the poems from Posle Rossii were finally translated into English. This happened when Pages from Tarusa, an English translation of large portions of the controversial Soviet collection, appeared in $1964 .{ }^{6}$

The translation of "Pis'mo" is to be credited to a fine contemporary English-American poet, Denise Levertov. When Pages from Tarusa was reviewed in the American press, critics, including those of the special journals devoted to Slavic studies, were unanimous in their praise of the high quality of Denise Levertov's translations. "A Letter" was apparently the most admired of her translations, for it has been reprinted in a special edition of TriQuarterly devoted to "Creativity in the Soviet Union" (although a poem written by the exiled Tsvetaeva in Czechoslovakia in 1923 would hardly seem pertinent to that general topic). It had evidently not occurred to any of the enthusiastic critics to compare the translation

5 Tarusskie stranitsy (Kaluga, 1961). Tsvetaeva's prose and poetry, mainly selections from Posle Rossii, is on 252-61 (including "Pis'mo," with one misprint, 257-58).

6 Andrew Field, ed., Pages from Tarusa (Boston, 1964). The five poems by Tsvetaeva were translated by Denise Levertov (four) and Andrew Field (one). The ordering of the poems, based on that of the Soviet original of the book, places a juvenile poem written by Tsvetaeva at the age of 17 ("Osen' v Taruse," first printed in Volshebnyi fonar' [Moscow, 1912], 43) in the midst of the sophisticated, mature poems from Posle Rossii. No dates are provided, and the style of Denise Levertov's English translation leaves no doubt that she was unaware of the tremendous stylistic difference between the early poem and the later ones. The volume also contains Tsvetaeva's prose memoir "Khlystovki" (Women of the flagellant sect), ably translated by Collyer Bowen as "The Kirillovnas." When this memoir, originally published in Paris as part of a series of Tsvetaeva's family memoirs (Vstrechi, no. 6 [1934], 243-48), was reprinted in Tarusskie stranitsy, the title was changed to "Kirillovny," possibly to avoid undesirable religious implications. The American translator (or his editor), apparently unaware of the original title, retained the Soviet substitution.

7 Marina Tsvetaeva, “A Letter," trans. Denise Levertov, TriQuarterly, [no. 3] (Spring 1965): 64. The issue also contains Andrew Field, "A Poetic Epitaph: Marina Tsvetaeva's Poems to Blok," and three poems translated by Lydia Pasternak Slater (57-63). 
of "A Letter" with its Russian original, yet such a comparison is highly instructive and points out most vividly both the dangers of translating complex poetry without sufficient qualification and the ease with which experts will accept and praise what is in fact a catastrophic bungle.

\section{Письмо}

Так писем не ждут,

Так ждут-письма.

Тряпичный лоскут,

Вокруг тесьма

Из клея. Внутри-словцо.

И счастье. И это-всё.

Так счастья не ждут,

Так ждут-конца:

Солдатский салют

И в грудь-свинца

Три дольки. В глазах красно.

И только. И это-всё.

Не счастья-стара!

Цвет-ветер сдул!

Квадрата двора

И черных дул.

(Квадрата письма;

Чернил и чар!)

Для смертного сна

Никто не стар!

Квадрата письма.

The poem is carefully structured. The two six-line stanzas (lines 1-12) develop two contrasting images, the contrast being reinforced by the fact that the second stanza recapitulates the syntactic and the semantic structure of the first one. The two four-line stanzas alternate the content of the first twelve lines in compressed form, while line 21 sums up the message of the entire poem. 
Lines 1-6 state the poet's yearning for a letter. The meaning of the first two lines is: This is not how you (they, one, people) wait for letters (pisem); this is how you wait for a letter (a particular expected letter, the letter: genitive singular pis'má). Tsvetaeva, with her phenomenal feeling for the nuances of spoken Russian, based the structure of the entire poem on an elementary fact of Russian grammar: the government of the verb zhdat', "to wait." The genitive plural in line 1 (the case of the direct object of a negated verb and/or the case required by the given verb) is combined and contrasted with a slightly different kind of genitive in the second line (a clear case of verb government). This sort of grammar-school parsing probably never occurred to Tsvetaeva or to her Russian readers-they would take the grammatical aspects of the poem for granted. But a translator has to be aware of it, for the government of the verb zhdat' is what determines the meaning and the structure of the remainder of the poem. Here is Denise Levertov's equivalent of Tsvetaeva's first stanza: ${ }^{8}$

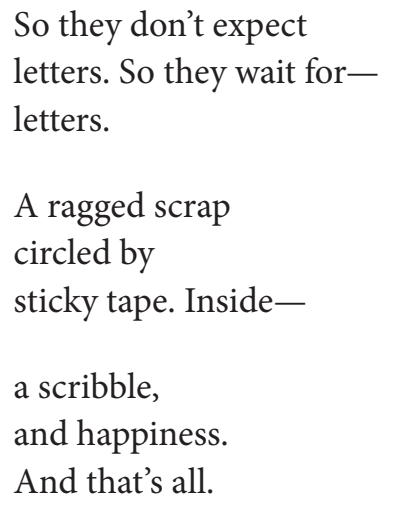

It is easy to see what has happened. The last word of line 2 has been read with an incorrect stress and mistaken for the accusative plural form. Yet at least three things point overwhelmingly to the fact that Tsvetaeva meant pis'má and not pis'ma in line 2: the government of the verb zhdat', the stress required by the meter, and, if that were not enough, the rhyming of this word with tes'má, which certainly admits no other stress. And so in the English version the contrast between letters in general and a particular expected letter-the whole point of the beginning of the poem-has

8 Denise Levertov's translation is cited here from Field, Pages from Tarusa, 288-89. 
been lost (the English definite article could have done the job so well). Instead, we get three lines with a vaguely Brooklynese-Yiddish intonation and almost no meaning at all. Tsvetaeva's Vokrug tes'ma / Iz kleia ("A braid of glue around the edges") is a mildly metonymic description of an ordinary envelope; Denise Levertov's "circled by / sticky tape" suggests some exotic and messy-sounding postal customs and difficulties with the vocabulary of the original. "A scribble" is a poor substitute for the warm and casual slovtso that Tsvetaeva uses to describe the contents of the desired missive.

The second stanza of the original is an example of the kind of parallel construction that is so typical of the later Tsvetaeva. The letter that was so joyously expected in the first stanza may also bring her unhappiness. It may indicate that the friendship she values so highly is ended. So the second stanza recapitulates the structure of the first one, but this time the arrival of the letter is visualized in terms of an execution by a firing squad. This the translator apparently understands, but since she missed the point of the first stanza she is unable to do justice to the nuances of the second one:

So they don't expect

happiness. So they expect-

the end.

A soldierly

salute, and

three slugs of lead in the breast.

Their eyes are red, and just that.

That's all.

Things become quite catastrophic again at the equivalent of Tsvetaeva's lines 11 and 12. In Russian, everything goes red before the eyes of the condemned and shot person or persons, who, as the very expressive I tol'ko suggests, experience an utter sense of finality. "Their eyes are red, / and just that," which Miss Levertov offers us at this point, only testifies that the text of the original has not been understood. The very subtle ambigu- 
ity of the repeated last phrase of the two stanzas (I eto-vse), conveying plenitude in the first stanza ("And this is everything," i.e., everything one needs), but futility and finality in the second one ("And that is all there is," i.e., all there will ever be) is not felt within the context of the English version.

After line 12, the remainder of Tsvetaeva's poem becomes elliptic and consists predominantly of verbless clauses, with most of the nouns in the genitive case. Extreme syntactic ellipsis is one of Tsvetaeva's favorite and most typical devices. The comprehension of her elliptic speech in the second half of the poem hinges on two simple things: the realization that the poet is referring to herself in all the impersonal "you" or "they" constructions and that the basic grammatical fact of the entire poem is the requirement that the masculine or neuter direct object of the verb zhdat' be in the genitive case. The verb itself, firmly and memorably established in the first two stanzas, need no longer appear: the case that it governs will unfailingly suggest it to the native Russian ear. In Tsvetaeva's mature poetry, the reader is often required to supply the omitted verbs that are represented only by their objects in the oblique cases; a translator of this particular poem is hopelessly lost if he fails to account for all those genitives in elliptical clauses.

A possible English literal version of lines 13-21, with the ellipses filled out in brackets, would read as follows:

[I] no [longer expect] happiness-[I am] too old [for that]!

[My] bloom - the wind blew it away!

[I am waiting for] the square of a courtyard

And for black muzzles of rifles.

([I am waiting for] the square of a letter:

For ink and magic!)

No one is too old

For the sleep of death.

[I am waiting for] the square of a letter.

There may be other ways of conveying in English the implications of Tsvetaeva's ellipses; a different English version is needed, if the poetic quality 
of the original is to be perceived. But, basically, this is what these lines mean in the Russian. Denise Levertov's version of this part of the poem is:

It's not happiness, old girl!

The wildflower color-

the wind blew it away.

A square courtyard and black thoughts.

Of a square letter, ink, sorcery.

When it comes to death, the

last dream, no one's

old.

A square letter.

Syntactic ellipses were not even noticed. Simple idioms, e.g., stará, were misunderstood. Because of a misprint in Tarusskie stranitsy, the genitive plural $d u l$ "rifle muzzles" was misread as dum "thoughts," an error which could have been avoided by a simple check of the original in Posle Rossii, available in most major libraries. The contrast between being too old for happiness and not being too old for death, which dominates the final portion of the poem, was simply overlooked.

It is dismaying to have to write all of this about a translation by Denise Levertov, a poet for whom I have great admiration. What, in the long run, is wrong with this translation (and with numerous others like it) is not any given mistake or set of mistakes, but the sheer idea of translating a poem which the translator understands neither structurally nor semantically. The able poet and the editor of the volume in which her translation first appeared (Andrew Field, who has elsewhere shown himself to be a capable propagandizer of Russian literature and an alert observer of the Soviet literary scene), in their desire to acquaint the American public with the work of a Russian poet they obviously admire, have overlooked considerations so basic and so self-evident that one would think they need not be mentioned at all. 
Marina Tsvetaeva is a difficult poet to translate. Of the few examples of her work available in English, the rhymed translations of Boris Pasternak's sister, Lydia Pasternak Slater, are by far the finest, both in their fidelity to the original and in their literary sophistication. Translations of Tsvetaeva's poetry by Olga Andreyev Carlisle ${ }^{9}$ and by Dimitri Obolensky ${ }^{10}$ are evidently not intended as poetic versions: they aim only at conveying the basic meaning of the Russian original. The English version of "A Letter" is intended to be an English poetic equivalent of the Russian original. It is based on a procedure that is becoming more and more widely practiced as the interest in Russian twentieth-century poetry spreads among American intellectuals. Denise Levertov has had the collaboration of unnamed persons who are presumably specialists in Russian language and Russian poetry. Here is how this translating procedure is described by the editor of Pages from Tarusa: "The poetry translations have been done from literal versions and metrical schemes supplied to the poets, in addition, of course, to oral readings. While there is a close proximity to the originals in all instances, the poets have taken certain liberties. The poems stand first as English poems in their own right, the only valid standard, it seems to me, by which to judge poetry translations."11

There can be no reasonable objection against this method of translating poetry. On occasion it has proven to be spectacularly successful, as for example in W. H. Auden's version of Bella Akhmadulina's poem "Volcanoes," which is not only faithfully rendered, but vastly superior as poetry to the rather undistinguished Russian original. ${ }^{12}$ But, as the above comparison of Tsvetaeva's poem with its English translation demonstrates, this method has a built-in danger that is very real indeed. The poet-translator who cannot read the original is completely at the mercy of an informant whose competence he cannot evaluate. Given a garbled version of the original poem as a point of departure, the most resourceful or

9 Olga Andreyev Carlisle, Voices in the Snow (New York, 1962), passim. [SK reviewed this (and another) anthology elsewhere at length, criticizing the selection and lamenting - "but carp we must," he writes - the quality of the trots provided the major American poets who were contributing to the volume (Simon Karlinsky, "Hosting Russian Poetry," Nation, 7 July 1969, 28-30).-Ed.]

10 Dimitri Obolensky, The Penguin Book of Russian Verse (Baltimore, 1962), 363-68.

11 Field, Pages from Tarusa, xiii.

12 Bella Akhmadulina, "Volcanoes," trans. W. H. Auden, Encounter 20, no. 4 (April 1963): 53. 
inspired translator becomes helpless. Whole vast areas of twentieth-century Russian poetry await translators, but if their translations are to be of any value at all these translators have, as a minimal requirement, to be able to understand the basic meaning, the structure, and the implication of the text they are translating. Some recent translations of Tsvetaeva, Pasternak, and Mandelstam, and especially the selection of Anton Chekhov's letters edited by Lillian Hellman and now available in paperback, full of the most unbelievable mistranslations and howlers on its every page, ${ }^{13}$ show that this minimal condition is not as absurdly obvious as it might appear to some. The problem of faulty, shoddy translations of Russian literature into English is as much with us today as it was in the days of Marian Fell and Constance Garnett. Denise Levertov's translation, spotlighted in this paper at length and perhaps a little unfairly, serves as a handy illustration of what happens when the minimum-comprehension criterion is not met. As Marina Tsvetaeva herself has remarked about a critical article by Ivan Bunin: "Luchshe nikak, chem tak!"14

This skillful explication de texte demonstrates SK's extraordinary expertise in dealing with problems of translation from Russian to English, particularly of works as complex semantically, lexically, and rhythmically as Tsvetaeva's poetry. Nearly every review of English-language works on Russian literature he wrote exhibits a similar concern. Elaine Feinstein, another translator-and later biographer-of Tsvetaeva, emerged relatively unscathed from under his scrutiny:

Many of the things that make Tsvetaeva the poet she is are missing from [Elaine] Feinstein's translations. There are no poetic fireworks, no virtuosity, none of the verbal music of the originals. The parallel syntactic constructions, the repetitions of some key words around which a poem is often built are likewise not to be found in the English. But also, by and large, there are almost no comprehension problems. Mrs. Feinstein has translated Tsvetaeva with fidelity and at times with

13 The Selected Letters of Anton Chekhov, ed. Lillian Hellman (New York, 1965).

14 "Better not at all than like this!" Marina Tsvetaeva, "Poet o kritike," Blagonamerennyi (Brussels, 1926), 2:118. 
remarkable resourcefulness. It is a measure of the shoddiness of recent translations of modern Russian poetry that the honesty and integrity of Elaine Feinstein's translation should seem to us such an unprecedented luxury. ${ }^{15}$

SK once designated the devices common to the poetry of Tsvetaeva and Boris Pasternak (and the difficulty of rendering of it into English), in a devastating review of two translations from Pasternak: "sudden shifts and compressions of meaning, emphasis on the phonetic and the lexical aspects of the poetic craft ... syntactic ellipses frequently found in Russian colloquial speech."16 (For SK's discussion of a specific link between the two poets, see below his essay "Pasternak, Pushkin and the Ocean in Marina Tsvetaeva's From the Sea.") In what is perhaps his final public statement, over a quarter of a century on, about Tsvetaeva-and after numerous publications of his own on the poet, including two book-length monographs-SK reviewed positively a study of intertextuality in Tsvetaeva's longer works by Michael Makin. ${ }^{17}$ He did, however, yet again find it necessary to take an author to task for lapses in translation, "frequently out of focus or simply sloppy," errors that might often be avoided by "looking things up or checking with native speakers."

Pasternak's early prose, like Tsvetaeva's, makes many of the same demands as his poetry, and may be nearly as difficult to translate. See the following excerpts from SK's highly positive review -in which he also praises the translator's "brilliant introduction"—of Angela Livingstone's excellent annotated English edition of Pasternak's essays, his autobiography A Safe Conduct, and his speeches and essays:

In all things I would like to reach

Their very essence.

15 Review of Selected Poems, by Marina Tsvetaeva, trans. Elaine Feinstein, foreword by Max Hayward (New York: Oxford University Press, 1971), Russian Review 32 (January 1973): 101-2.

16 “The Crime Against Pasternak," review of The Poems of Doctor Zhivago, by Boris Pasternak, trans. Eugene M. Kayden (Kansas City, MO: Hallmark Editions, ca. 1971), and Sister My Life, by Boris Pasternak, trans. Philip S. Flayderman (New York: Washington Square Press, 1967), Nation, 22 January 1968.

17 Review of Marina Tsvetaeva: Poetics of Appropriation, by Michael Makin (Oxford: Clarendon Press, 1994), Times Literary Supplement, 30 December 1994. 
These two lines open the first poem in Boris Pasternak's last collection of verse, When the Weather Clears Up, begun in 1956 and completed in 1959, one year before his death. Essences, in life and in art, are what much of Pasternak's poetry and prose were about. He strove to uncover, as he wrote in the poem just cited, "the crux of bygone days, their cause, the foundations, the roots, the very core." And yet, as the poet Marina Tsvetaeva, his passionate admirer and correspondent, warned in an essay (1933), readers' response to Pasternak often reminded her of dialogues in Alice in Wonderland. Reality, as perceived by Pasternak, resembles the ordinary, pragmatic reality, but he viewed and described it from an angle all his own, an angle whose eccentricity was less apparent to him than to some of his readers. This accounts for his honest surprise at the storm and fury unleashed in the Soviet Union by the publication abroad of his novel Doctor Zhivago and the awarding to him of the Nobel Prize....

His understanding of the terms "realism" and "realistic" was so idiosyncratic that it enabled him to consider the music of Chopin, the poetry of Verlaine and the plays of Heinrich von Kleist as representative works of realist art. For Pasternak, art was realistic "in that it did not invent metaphor, but found it in nature and faithfully reproduced it."

Similarly, the terms "romantic" and "romanticism" were appropriated by the poet "for quite a narrow and negative meaning. 'Romantic' means whatever is made up, ungenuine, and not experienced in real life." Other literary and philosophical terms, such as "identity" or "originality," underwent semantic mutations, while "subjectivity" and "objectivity" became, in Livingstone's words, "quite unmoored and float about until we are dizzy." This is not willfulness or caprice. Pasternak saw everything "in the light of its ability to change, to shift and to reveal itself as extraordinary." Critics have often pointed out Pasternak's power to see the world anew, to discover in humdrum everyday trifles aspects that had never been observed before. This also applies to his theoretical writings about art. ${ }^{18}$

In point of fact, SK's admiration for the poetry of Pasternak preceded his intense involvement with the equally singular lyric voice of Tsvetaeva. We in-

18 Simon Karlinsky, "Realistically Speaking," Times Literary Supplement, 22 November 1985. 
clude here an except from one of his earliest published writings, an introduction to German translations of Pasternak's poetry, dating from 1950:

For Boris Pasternak poetry was never a form of magic or ritual, but always a strict exercise in art, an exercise that was both conscientious and universal. Pasternak did not indulge in formal experiments; his poetry is new and unusual all the same. He uses conventional poetic forms for expressionistically subjective content, for a system of crisscrossing allusions, and for a brilliance that was unheard of in Russian poetry.

Boris Pasternak was born in 1890, the son of Leonid Pasternak, a well-known portrait painter. He studied in Germany at the University of Marburg. It was perhaps there that he began greatly to admire Goethe and Lenau. Other literary models are, in particular, Shakespeare, Pushkin, and Lermontov.

Pasternak's first poems were published in 1912. In them we can already discern the fundamental tone, the leitmotif of his future poetic creation: the constant amazement over the miracle of being alive.

Ilya Erenburg, who in the 1920s wrote about Pasternak's poetry, praised him for having again confirmed the right to existence of "chamber poetry"- a poetry in the vein of chamber music, written in small format, for a more sophisticated and therefore smaller public. In the years following, it became clear that Pasternak's reading public was larger than Erenburg had believed.

The first two volumes of Pasternak's poetry appeared before the Revolution. They were called A Twin in the Clouds and Above the Barriers. In these volumes Pasternak's specific style is clearly marked. His meters are strictly classical, but the rhymes are unconventional; sometimes he uses near rhymes, just as Aleksandr Blok did. The whole structure of Pasternak's poetry is characterized by the presence of a lively spirit that is hungry, perhaps too hungry, for life, almost uncanny in its scintillating vitality, built on the basis of a staccato rhythm. A concentration of these traits can be found in Pasternak's third volume of poetry, My Sister Life. This volume was written in 1917 and published in Berlin in 1923. A remarkable book, it was apparently created at the time when Pasternak left the literary group LEF. Mayakovsky, who was then the recognized and authoritative leader of this group, propagated the idea that the only task of poetry was its usefulness for the revolutionary cause. This conception was, of course, entirely alien to the passionate and individualistic poetry of Pasternak, and he had the courage to admit this 
by breaking with LEF. In My Sister Life, the poem "Definition of Poetry" develops Pasternak's unique conception of literary counterpoint-two completely different themes are simultaneously developed to a parallel effect, while safeguarding the unity of the poetic whole. The poet lives through and transforms his life experience so intensely that his occasional literary signals can be understood only by readers who have sufficient imagination to understand his comprehensive metaphors and allusions. In his collection of poems Themes and Variations, Pasternak raises his purely poetic virtuosity to heights that had never been reached in Western literature. These short poems are the literary equivalent of the etude as a musical genre. They stimulate and astonish us, but it cannot be denied that their charm is mainly of an intellectual nature. The main group of poems in this volume consists of variations on the topic of Pushkin in the Crimea; they comprise a poetic description of a well-known portrait that shows Pushkin on the Crimean sea coast. Among the six subsequent variations, the first is written in Pasternak's most extreme fashion, and it deals with the conflict of Pushkin's Russian environment, on one hand, and his alleged African origins, on the other; the second variation is written in Pushkin's own style and provides an impressive maritime picture, with Pushkin gazing into "the misty twilight of shipwrecks."

After this third volume of poems Pasternak wrote two long narrative poems, Lieutenant Schmidt and 1905, a short novel, Lyuvers's Childhood, and an autobiography. In the 1930s it became increasingly difficult for him to publish his works (his most important writings of the 1920s were all published abroad), and-unwilling to make any compromise, either in his style or in his choice of topic - he turned to the art of literary translation. ${ }^{19}$

19 Translated by Joachim Klein, from S. Karlinsky, "Drei russische Dichter," Das Lot 4 (October 1950): 48-50. 